$$
\text { DOE/ER/13469--T2 }
$$

PROGRESS REPORT

DOE/ER/13469--T2

DE92 013503

\author{
DEPARTMENT OF ENERGY \\ (DE-FG03-86ER-13469)
}

\title{
"RESEARCH IN CHEMICAL KINETICS"
}

\author{
Department of Chemistry \\ University of California \\ Irvine, California 92717
}

Progress Report on work carried out during the contract period from

January 1, 1991 to December 31, 1991

\author{
PRINCIPAL INVESTIGATOR: F. SHERWOOD ROWLAND \\ DISCLAIMER
}

\begin{abstract}
This report was prepared as an account of work sponsored by an agency of the United States Government. Neither the United States Government nor any agency thereof, nor any of their employees, makes any warranty, express or implied, or assumes any legal liability or responsibility for the accuracy, completeness, or usefulness of any information, apparatus, product, or process disclosed, or represents that its use would not infringe privately owned rights. Reference herein to any specific commercial product, process, or service by trade name, trademark, manufacturer, or otherwise does not necessarily constitute or imply its endorsement, recommendation, or favoring by the United States Government or any agency thereof. The views and opinions of authors expressed herein do not necessarily state or reflect those of the United States Government or any agency thereof.
\end{abstract}

MASTER

P.t. 
$\therefore 2, j=-$

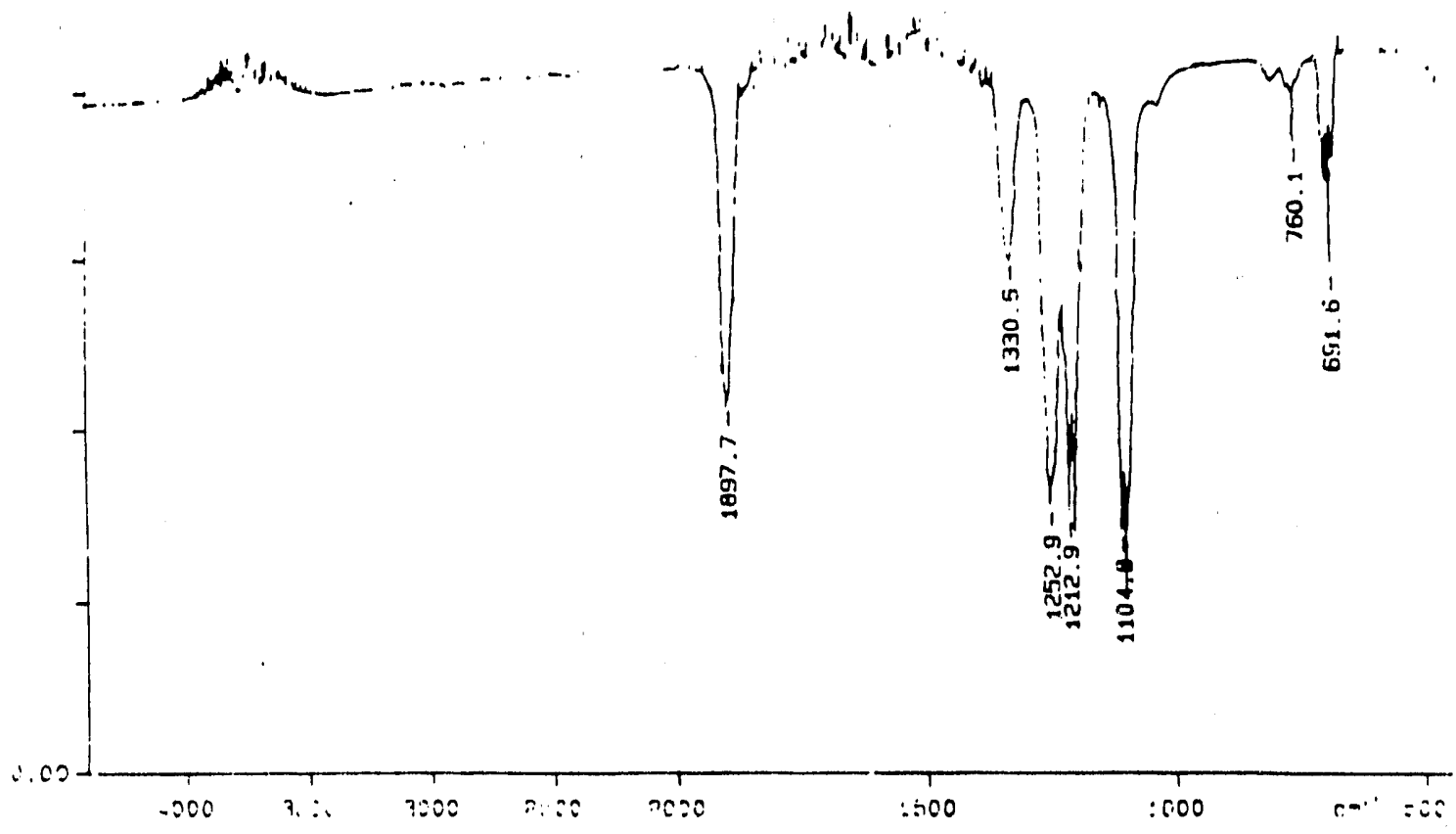

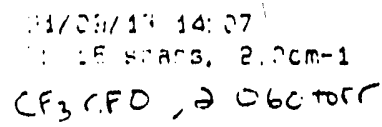

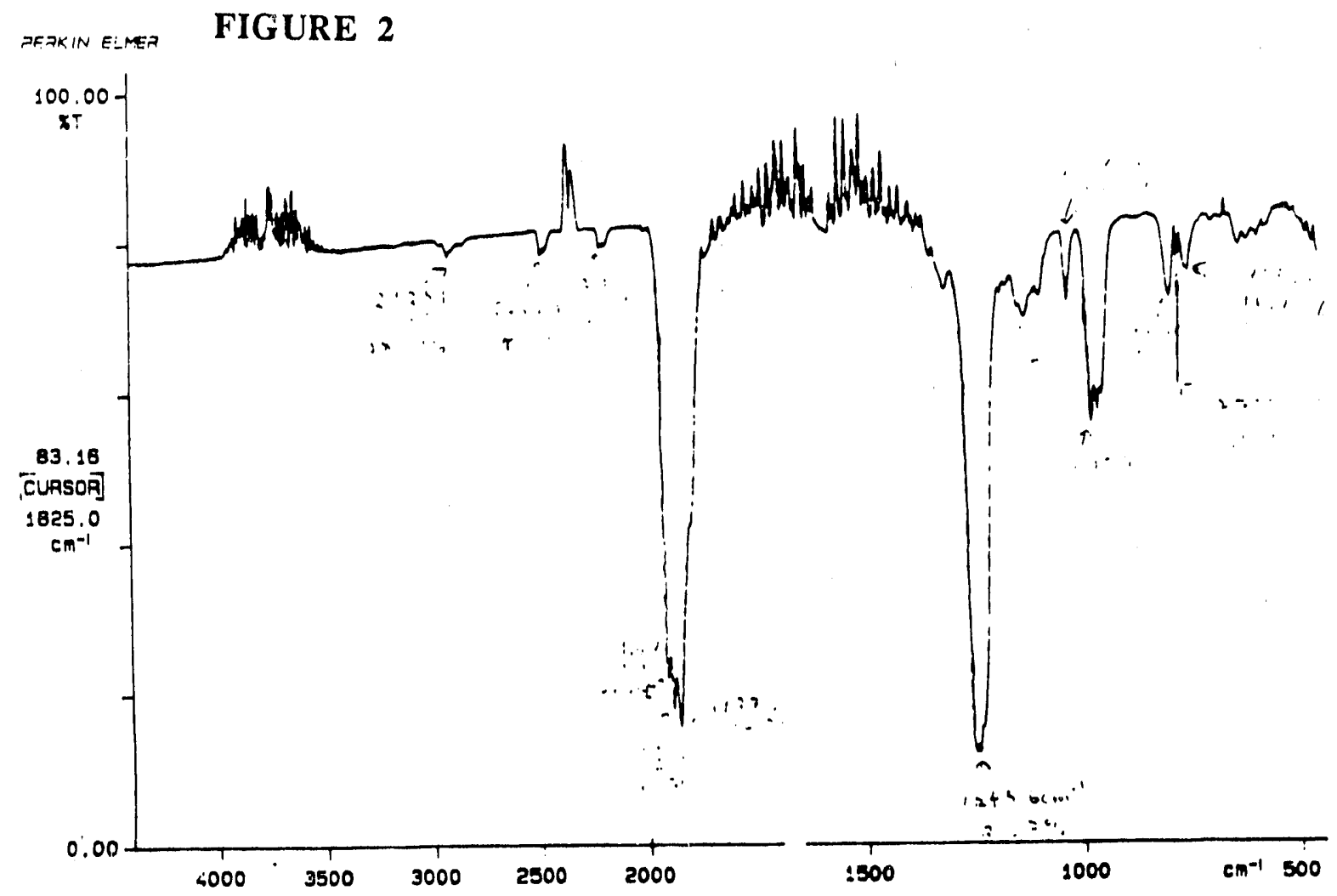

9:; 24 ing :3: 4::

$Y:$ :6 acona, 4.0 Cm-1

Corbony? Fiuorsde [CFzo], 6.7 torr 
FIGURE 3

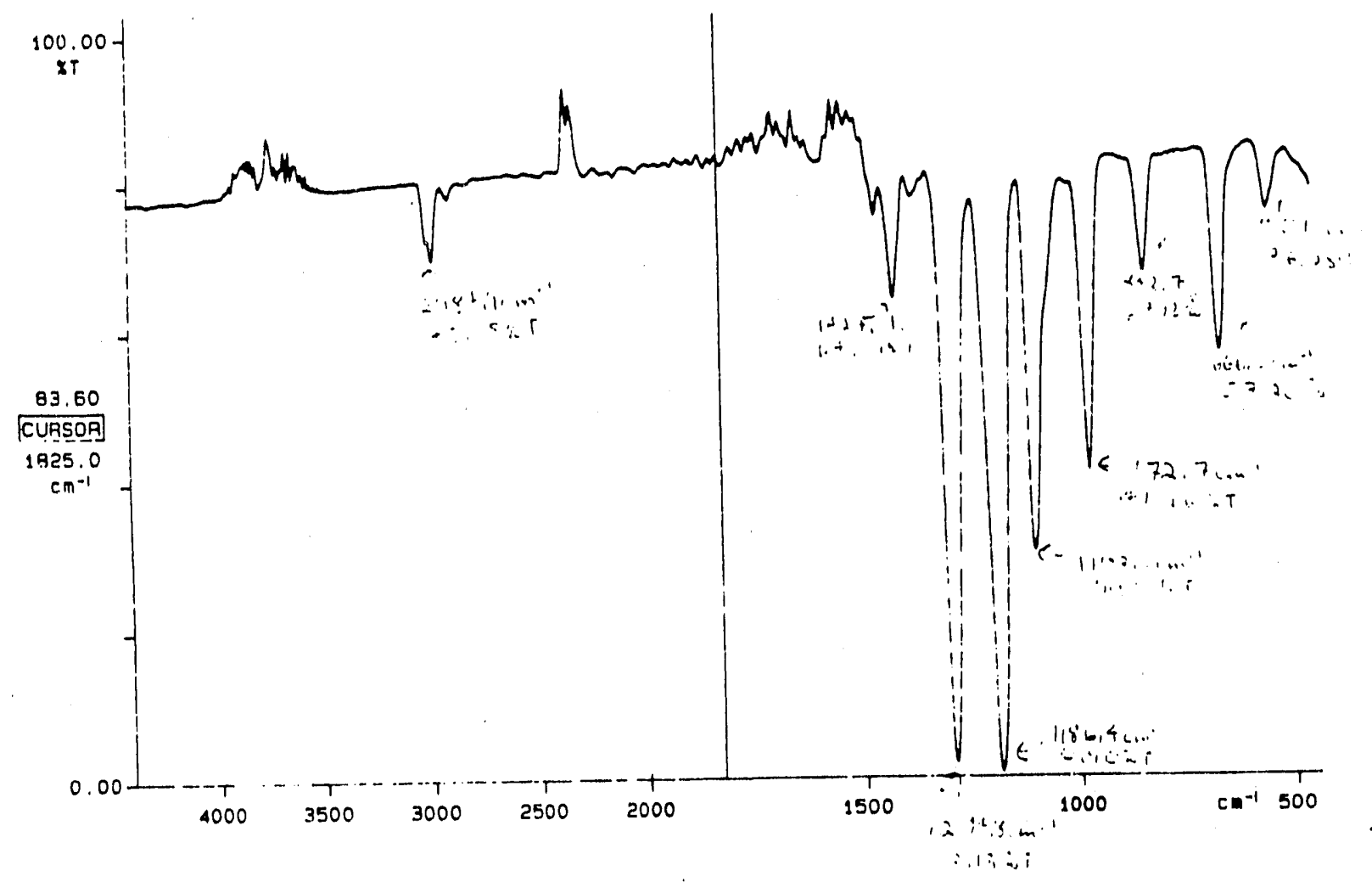

91/04/02 11: 52 benzlamine

$Y$ : 16 scans, $16.0 \mathrm{~cm}-1$. apod weak

1. 1. 1, 2 tetrafluoroethane + - wr

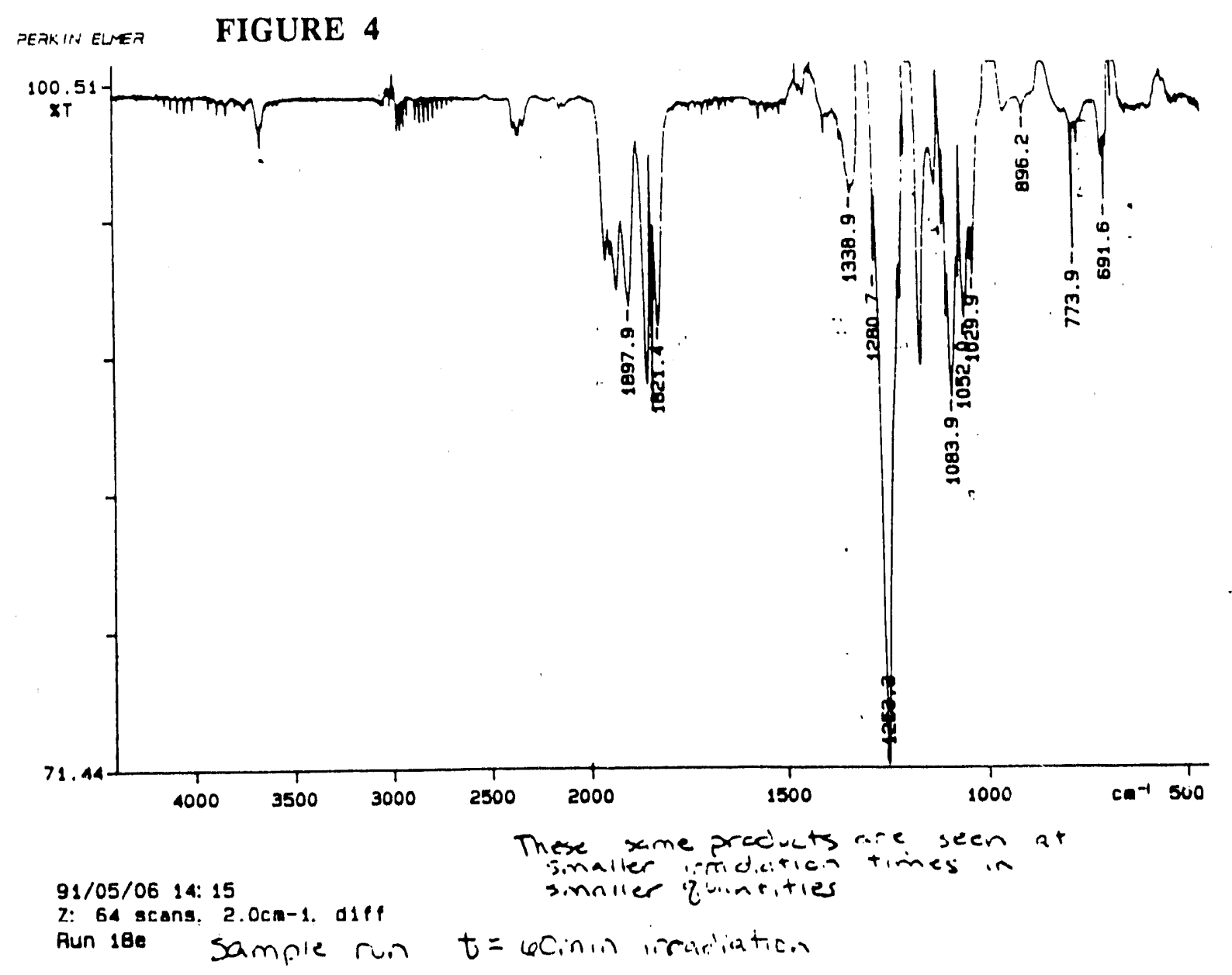


The expected reactions $\mathrm{M} \mathrm{c}$ as follows (analogous mechanism to reference): ${ }^{3}$

$$
\begin{aligned}
& \mathrm{CF}_{3} \mathrm{CH}_{2} \mathrm{~F}+\mathrm{Cl} \rightarrow \mathrm{CF}_{3} \mathrm{CHF}+\mathrm{HCl} \\
& \mathrm{CF}_{3} \mathrm{CHF}+\mathrm{O}_{2} \rightarrow \mathrm{CF}_{3} \mathrm{CHFO} \\
& 2 \mathrm{CF}_{3} \mathrm{CHFO} \\
& \mathrm{CF}_{3} \mathrm{CHFO}+\mathrm{O}_{2} \rightarrow \mathrm{CF}_{3} \mathrm{CHFO}+\mathrm{O}_{2} \\
& \mathrm{CF}_{3} \mathrm{CHFO}+\mathrm{O}_{2}+\mathrm{CF}_{3} \mathrm{CF}(\mathrm{O}) \\
& \mathrm{CF}_{3} \mathrm{CHFO} \rightarrow \mathrm{FO}_{2}+\mathrm{CF}_{3} \mathrm{CH}(\mathrm{O}) \\
& \mathrm{CF}_{3} \mathrm{CH}(\mathrm{O})+\mathrm{Cl} \rightarrow \mathrm{CH}(\mathrm{O}) \\
& \mathrm{CF}_{3} \mathrm{C}(\mathrm{O})+\mathrm{CF}_{3} \mathrm{C}(\mathrm{O})+\mathrm{HCl} \\
& \mathrm{CF}_{3} \mathrm{C}(\mathrm{O}) \mathrm{O}_{2} \rightarrow \mathrm{CF}_{3} \mathrm{C}(\mathrm{O}) \mathrm{O}_{2} \\
& \mathrm{CF}_{3} \mathrm{O} \rightarrow \mathrm{CF}+\mathrm{O}+\mathrm{CF}_{2}(\mathrm{O})
\end{aligned}
$$

Preliminary studies show $\mathrm{CF}_{3} \mathrm{CF}(\mathrm{O})$ and $\mathrm{CF}_{2}(\mathrm{O})$ to be products of this reaction. The effect of varying the irradiation time on the yields of these two products is shown in Figures 5 and 6 for two samples with different $\mathrm{O}_{2}$ concentrations. The presence of $\mathrm{CF}_{2}(\mathrm{O})$ suggests that $\mathrm{CF}_{3} \mathrm{CH}(\mathrm{O})$ might also be a product, as shown in the possible mechanism. The FTIR spectrum of $\mathrm{CF}_{3} \mathrm{CH}(\mathrm{O})$ has not yet been obtained due to the extreme difficulty in handling the material. Attempts will be made to prepare an authentic sample of $\mathrm{CF}_{3} \mathrm{CH}(\mathrm{O})$ for spectral measurement. $\mathrm{CHF}(\mathrm{O})$, expected from reaction $5 \mathrm{c}$, was not observed as a product in these runs. ${ }^{4}$

\section{Wavelengths Identified and Assumed in Figure 4}

\section{Wavelength (cm-1)}

691.6

760.1

773.9

896.2

1029.9

1052.0

1083.9

1212.2

1253.3

1280.7

1338.9

1821.4

1835.6

1849.6

1897.8

\section{Compound}

$\mathrm{CF}_{3} \mathrm{CF}(\mathrm{O})$

$\mathrm{CF}_{3} \mathrm{CF}(\mathrm{O})$

$\mathrm{CF}_{2}(\mathrm{O})$

To be identiiied

$\mathrm{CF}_{2}(\mathrm{O})$

To be identified

To be identified

$\mathrm{CF}_{3} \mathrm{CF}(\mathrm{O})$

$\mathrm{CF}_{3} \mathrm{CF}(\mathrm{O})$

To be identified

To be identified

$\mathrm{CClF}(\mathrm{O})^{\mathrm{a}}$

$\mathrm{CClF}(\mathrm{O})^{\mathrm{a}}$

$\mathrm{CClF}(\mathrm{O})^{\mathrm{a}}$

$\mathrm{CF}_{3} \mathrm{CF}(\mathrm{O})$

a By undetermined mechanism. See Reference 3.

Subsequent experiments will involve the influence of $\mathrm{O}_{2}$ concentration, the impact of the presence of $\mathrm{N}_{2}$, and a pressure study. This study may also be expanded to other hydrofluorocarbons and hydrochlorofluorocarbons. 

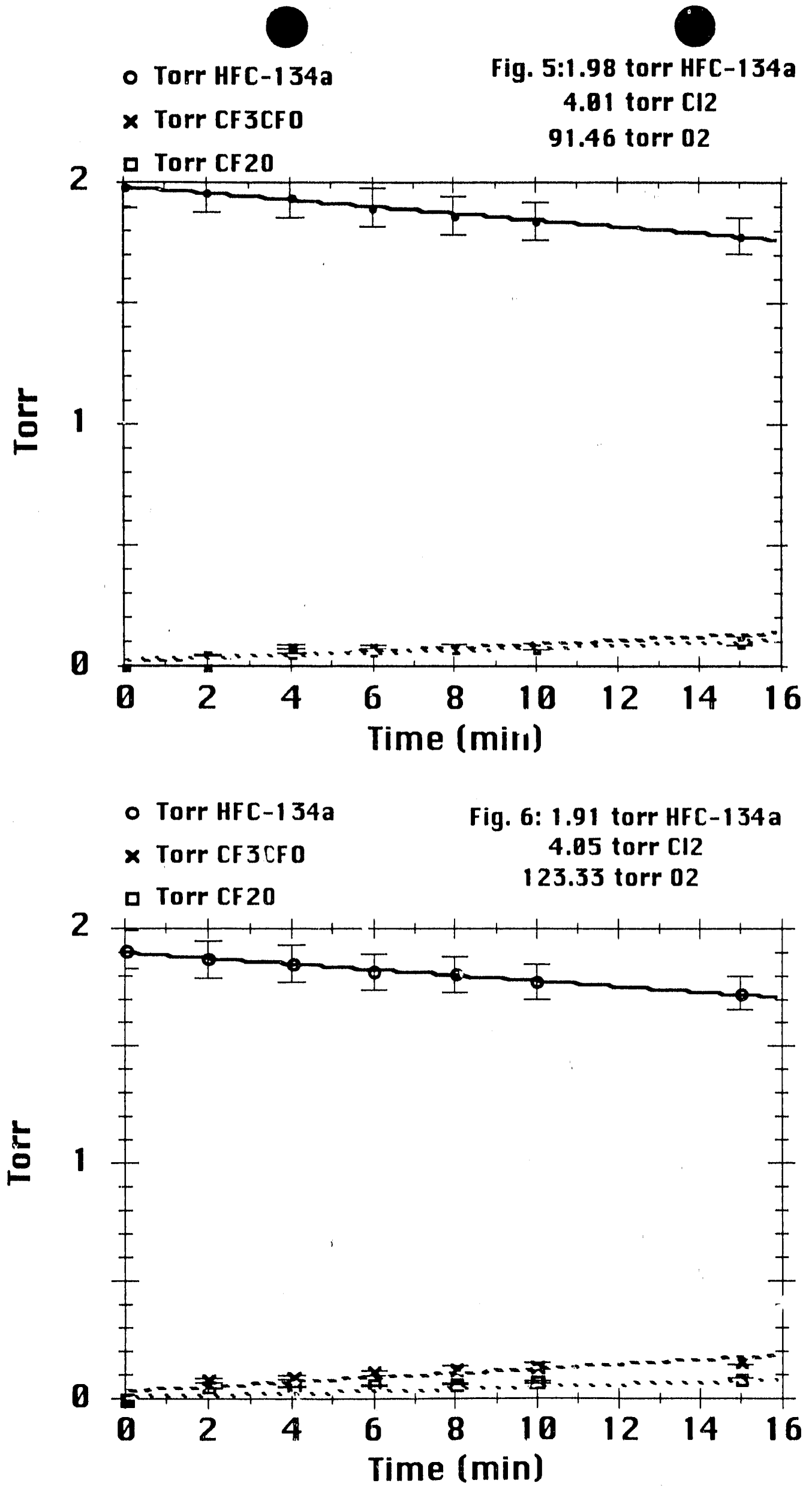


\section{REFERENCES FOR SECTION I}

1. Sukornick, B. "Potentially Acceptable Substitutes for the Chlorofluorocarbons: Properties and Performance Features of HFC-134a, HFC-123, and HCFC-141b", Int. J. Thermo., $1989,10,553-561$.

2. Gillotay, D.; Simon P. "Temperature Dependence of Ultraviolet Absorption Cross-Sections of Alternative Chlorofluoroethanes", J. Atmos. Chem., 1991, 12, 269-285.

3. Edney, E.O.; Gay,, B.W., Jr.; Driscoll, D.J. "Chlorine-Initiated Oxidation Studies of Hydrochlorofluorocarbons: Results for HCFC-123( $\left.\mathrm{CF}_{3} \mathrm{CHCl}_{2}\right)$ and $\mathrm{HCFC}-141 \mathrm{~b}$ $\left(\mathrm{CFCl}_{2} \mathrm{CH}_{3}\right)^{\prime \prime}$, J. Atmos. Chem., 1991, I2, 105-120.

4. Olah, G.A.; Kuhn, S.J. "Formylation with Formyl Fluoride: A New Aldehyde Synthesis and Formylation Method", J. Am. Chem. Soc., 1960, 82, 2380-2382. 


\section{ABSTRACTION REACTIONS BY THERMAL CHLORINE ATOMS WITH HFC-134a}

Thermalized ${ }^{38} \mathrm{Cl}$ atoms from the neutron irradiation ${ }^{1}$ of $\mathrm{CClF}_{3}$ were used to determine the relative rate constants for HFC-134a and other alkanes and haloalkanes versus a common competitor, vinyl bromide, at 4000 torr, with measurement of the decomposition product, $\mathrm{CH}_{2}=\mathrm{CH}^{38} \mathrm{Cl}$, formed following ${ }^{38} \mathrm{Cl}$ addition to $\mathrm{CH}_{2}=\mathrm{CHBr}^{2-5}$ Alkanes and haloalkanes with

$$
{ }^{38} \mathrm{Cl}+\mathrm{CH}_{2}=\mathrm{CHBr} \rightarrow \mathrm{C}_{2} \mathrm{H}_{3} \mathrm{Br}^{38} \mathrm{Cl}^{*} \rightarrow \mathrm{CH}_{2}=\mathrm{CH}^{38} \mathrm{Cl}+\mathrm{Br}
$$

well-known rate constants for reactions ${ }^{6}$ with chlorine atoms are chosen as the competitor molecules for the conversion of the measured relative rate constants onto an absolute scale.

Vinyl bromide proved to react too quickly with chlorine atoms to allow accurate measurement of the rate constant for $\mathrm{Cl}$ atom reaction with $\mathrm{HFC}-134 \mathrm{a}$ (Fig. 1). The common competitor was therefore changed to bromotrifluoroethylene. It was found by using ethane as a competing reagent that the formation of $\mathrm{CF}_{2}=\mathrm{CF}^{38} \mathrm{Cl}$ from $\mathrm{CF}_{2}=\mathrm{CFBr}$ at a total pressure of 4000 torr of $\mathrm{CClF}_{3}$ is about three times slower than the corresponding reaction with $\mathrm{CH}_{2}=\mathrm{CHB}^{-}$to form $\mathrm{CH}_{2}=\mathrm{CH}^{38} \mathrm{Cl}$.

$$
{ }^{38} \mathrm{Cl}+\mathrm{CF}_{2}=\mathrm{CFBr} \rightarrow \mathrm{C}_{2} \mathrm{~F}_{3} \mathrm{Br}^{38} \mathrm{Cl}^{*} \rightarrow \mathrm{CF}_{2}=\mathrm{CF}^{38} \mathrm{Cl}+\mathrm{Br}
$$

The reciprocal yields of $\mathrm{CF}_{2}=\mathrm{CF}^{38} \mathrm{Cl}$, with allowance for a $5 \%$ loss of total ${ }^{38}$ chlorine through hot reactions, are plotted against competitor ratios (see Fig. 2). These lines provide slopes whose ratios give the ratios of the respective rate constants. Methane and methyl chloride, whose rate constants for reaction with chlorine atoms are well-known, were used as the reference reactants.

\section{Measured Slopes and Rate Constants for Reactions of Chlorine Atoms with the Competing Reagents}

\author{
Competing
Reagent \\ $\mathrm{CH}_{4}$ \\ $\mathrm{CH}_{3} \mathrm{Cl}$ \\ $\mathrm{CH}_{3} \mathrm{~F}$ \\ $\mathrm{CH}_{3} \mathrm{~F}$ \\ $\mathrm{CH}_{3} \mathrm{~F}$ \\ HFC-134a
}

\begin{abstract}
Measured Slope
\end{abstract}

$.029 \pm .002$
$.159 \pm .013$
$.063 \pm .005$
$.0039 \pm .0003$

\section{K(298)}

(1.0土0.10) E-13

$(4.9 \pm 0.98) E-13$

$(3.61 \pm 0.10) \mathrm{E}-13$ $3.4 \mathrm{E}-13$

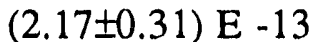

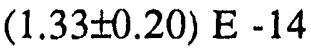

\section{Reference}

6
6
7
8
this work
this work
a

a Using methane as the reference line.

As seen from the above table, the ratio (5.48 \pm 0.59$)$ of the respective slopes measured for $\mathrm{CH}_{4}$ and $\mathrm{CH}_{3} \mathrm{Cl}$ agree within experimental error with the ratio of their respective rate constants $(4.9 \pm 1.1)$. However, the rate constant determined for $\mathrm{CH}_{3} \mathrm{~F}$ in our experiments is about $40 \%$ lower than the value reported in the literature. ${ }^{7}$ For chlorine atom reaction with HFC-134a, the present study indicates a rate constant of $(1.33 \pm 0.20) \times 10^{-14} \mathrm{~cm}^{3}$ molecule ${ }^{-1} \mathrm{~s}^{-1}$ at $298 \mathrm{~K}$. Additional confirmation of the rate constants determined for $\mathrm{CH}_{3} \mathrm{~F}$ and $\mathrm{HFC}-134 \mathrm{a}$ is being sought from further experiments using $\mathrm{H}_{2}$ as a reference reactant. As can be seen in Figure 2, the data points for $\mathrm{RH}=\mathrm{CH}_{4}, \mathrm{CH}_{3} \mathrm{~F}$ and $\mathrm{CH}_{3} \mathrm{Cl}$ appear to show a slight upward curvature suggesting lower measured yields of $\mathrm{CF}_{2}=\mathrm{CF}^{38} \mathrm{Cl}$ (than would be expected for a linear fit) at the higher $[\mathrm{RH}] /\left[\mathrm{CF}_{2}=\mathrm{CFBr}\right]$ ratios. Whether this curvature is caused by the involvement of non-thermal ${ }^{38} \mathrm{Cl}$ reactions is currently being checked through a temperature study ${ }^{9}$ of the different competitive systems. 


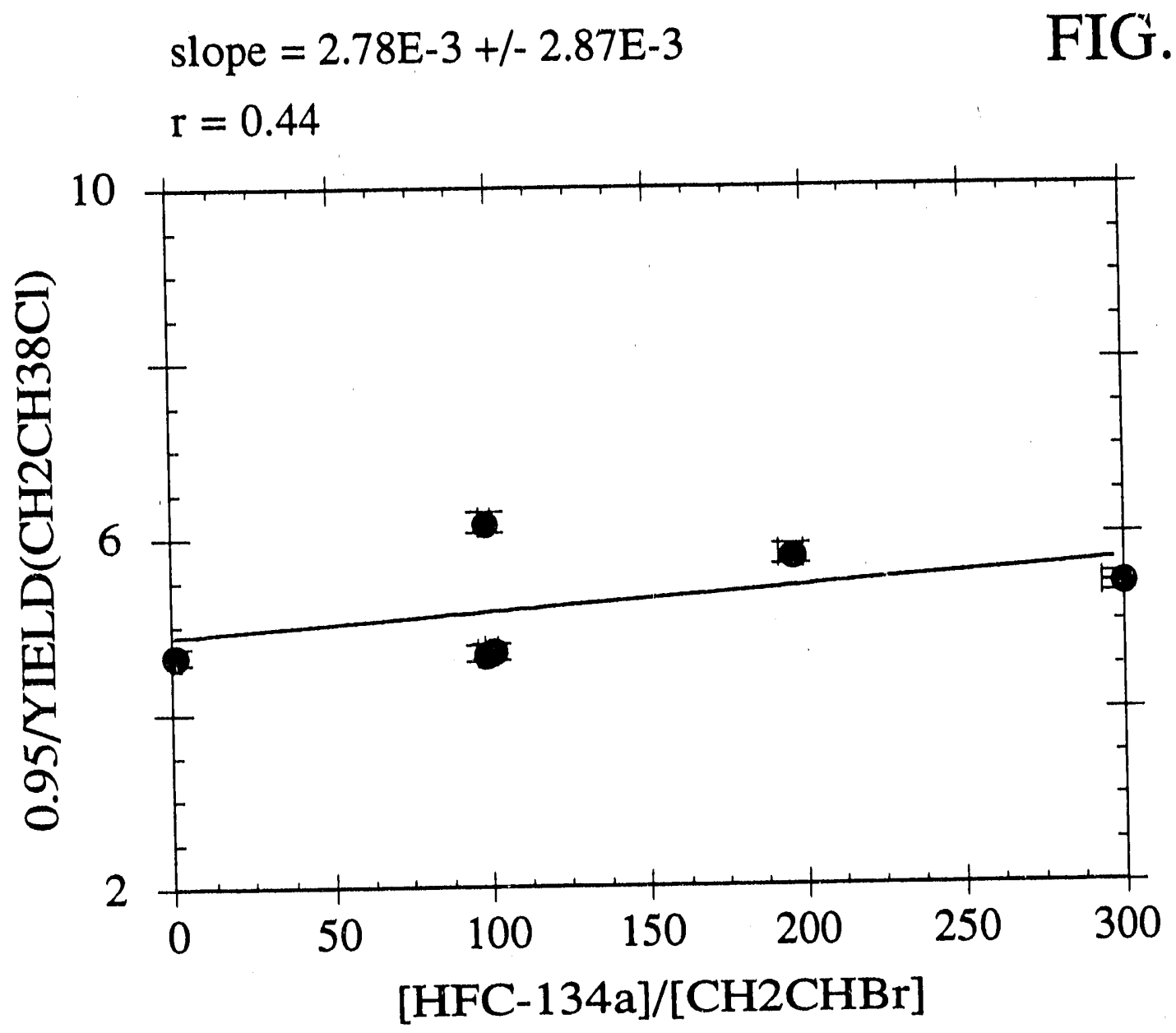



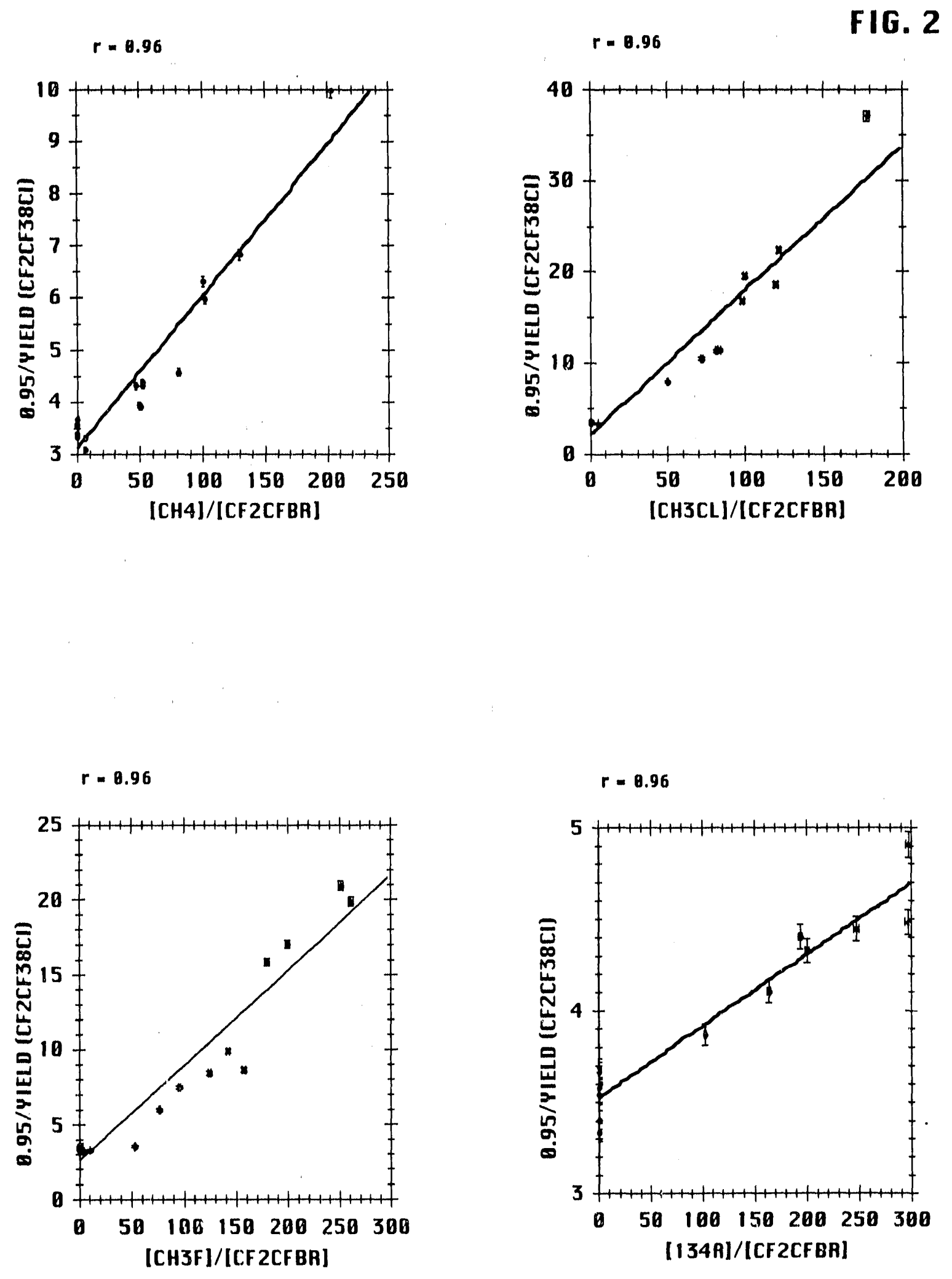


\section{REFERENCES FOR SECTION II}

1. Lee, F.S.C.; Rowland, F.S. "Thermal Chlorine-38 Atom Sources: Neutron Irradiation of $\mathrm{CClF}_{3}$ and $\mathrm{CCl}_{2} \mathrm{~F}_{2}$ ", J. Phys. Chem., 1977, 81, 1229-1235.

2. Lee, F.S.C.; Rowland, F.S. "Competitive Radiotracer Evaluation of Relative Rate Constants at Stratospheric Temperatures for Reactions of ${ }^{38} \mathrm{Cl}$ with $\mathrm{CH}_{4}$ and $\mathrm{C}_{2} \mathrm{H}_{6}$ vs. $\mathrm{CH}_{2}=\mathrm{CHBr} "$, J. Phys. Chem., 1977, 81, 86-87.

3. Iyer, R.S.; Rowland, F.S. "A Long-Lived $\mathrm{C}_{2} \mathrm{H}_{3} \mathrm{ClBr}$ * Radical from the Reaction of Atomic Chlorine with Vinyl Bromite", Chem. Phys. Lett., 1983, 103, 213-218.

4. Iyer, R.S.; Rogers, P.J.; Rowland, F.S. "Thermal Rate Constant for Addition of Chlorine Atoms to Ethylene, J. Phys. Chem., 1983, 87, 3799-3801.

5. Lu, E.C.-C.; Iyer, R.S.; Rowland, F.S. "Reaction Rates for Thermal Chlorine Atoms with H2S from 232 to $359 \mathrm{~K}$ by a Radiochemical Technique, J. Phys. Chem., 1986, 90, 19881990.

6. Demore, W.B.; Sander, S.P.; Golden, D.M.; Molina, M.J.; Hampson, R.F.; Kurylo, M.J.; Howard, C.J.; Ravishankara, A.R. "Chemical Kinetics and Photochemical Data for use in Stratospheric Modeling", Evaluation 9, NASA Panel for Data Evaluation, Publ. 90-1, Jet Propulsion Laboratory, Pasadena, CA, 1990.

7. Manning, R.G.; Kurylo, M.J. "Flash Photolysis Resonance Fluorescence Investigation of the Temperature Dependencies of the Reactions of $\mathrm{Cl}\left({ }^{2} \mathrm{P}\right)$ Atoms with $\mathrm{CH}_{4}, \mathrm{CH}_{3} \mathrm{Cl}_{1} \mathrm{CH}_{3} \mathrm{~F}$, $\mathrm{CH}_{3} \mathrm{~F}+$, and $\mathrm{C}_{2} \mathrm{H}_{6}{ }^{\prime \prime}, J$. Phys. Chem., 1977, 81, 291-296.

8. Atkinson, R. private communication, unpublished rate constant (without a reported error) for $\mathrm{CH}_{3} \mathrm{~F}+\mathrm{Cl}$. at $298 \mathrm{~K}, 1991$.

9. Lu, E.C.-C. Thesis Dissertation, "Kinetics of Some Reactions of Atmospheric Interest: Hydrolysis of Carbonyl Sulfice and Reaction Rates of Thermal Chlorine Atoms with Carbonyl Sulfide, Methanol, Hydrogen Sulfide, and Methyl Chloride", 1987. 


\section{CHLORINE ATOM REACTIONS WITH VINYL BROMIDE}

The addition of thermal chlorine atoms to $\mathrm{CH}_{2}=\mathrm{CHBr}$ has been previously studied by us using radioactive ${ }^{38} \mathrm{Cl}$ atoms. ${ }^{1}$ In those experiments carried out in the pressure range $50-4000$ torr, $\mathrm{CClF}_{3}$ was used as the bath gas and $\mathrm{HI}$ as the scavenger for collisionally stabilized radicals. $\mathrm{CH}_{2}{ }^{38} \mathrm{ClCH}_{2} \mathrm{Br}$ was observed as the chief product at high pressures with yields exceeding $75 \%$ at 4000 torr, while at low pressure, the major product was $\mathrm{CH}_{2}=\mathrm{CH}^{38} \mathrm{Cl}$. The obvious precursor for $\mathrm{CH}_{2}=\mathrm{CH}^{38} \mathrm{Cl}$ in these experiments is the vibrationally excited $\mathrm{CH}_{2} \mathrm{CHBr}^{38} \mathrm{Cl}^{*}$ radicals.

Collisional stabilization of these radicals, followed by reaction with $\mathrm{HI}$, would be expected to form $\mathrm{CH}_{3} \mathrm{CHBr}^{38} \mathrm{Cl}$. However, the yield of this product was always $<0.1 \%$. The observed dependence of the yields of $\mathrm{CH}_{2}{ }^{38} \mathrm{ClCH}_{2} \mathrm{Br}$ and $\mathrm{CH}_{2}=\mathrm{CH}^{38} \mathrm{Cl}$ on total pressure and $[\mathrm{HI}] /\left[\mathrm{CH}_{2}=\mathrm{CHBr}\right]$ ratios in these experiments could be fitted with either one of two proposed mechanisms. In mechanism (A), ${ }^{38} \mathrm{Cl}$ atoms added predominantly to the $\mathrm{CH}_{2}$ end of the olefinforming $\mathrm{CH}_{2}{ }^{38} \mathrm{ClCHBr}^{*}$ as in Reaction 1. Isomerization of these radicals to form $\mathrm{CH}_{2} \mathrm{CHBr}^{38} \mathrm{Cl}^{*}$ by a $1,2-\mathrm{Cl}$ atom shift

$$
\begin{aligned}
& { }^{38} \mathrm{Cl}+\mathrm{CH}_{2}=\mathrm{CHBr} \rightarrow \mathrm{CH}_{2}{ }^{38} \mathrm{ClCHBr}^{*} \\
& \mathrm{CH}_{2}{ }^{38} \mathrm{ClCHBr}^{*} \rightarrow \mathrm{CH}_{2} \mathrm{CHBr}^{38} \mathrm{Cl}^{*} \\
& \mathrm{CH}_{2} \mathrm{CHBr}^{38} \mathrm{Cl} * \rightarrow \mathrm{CH}_{2}=\mathrm{CH}^{38} \mathrm{Cl}+\mathrm{Br}
\end{aligned}
$$

(Reaction 2), followed by the rapid loss of $\mathrm{Br}$ (Reaction 3) resulted in the formation of the product $\mathrm{CH}_{2}=\mathrm{CH}^{38} \mathrm{Cl}$. This "anti-Markovnikov" addition of $\mathrm{Cl}$ followed by Reactions 2 and 3 has been previously proposed to explain the formation of $\mathrm{CH}_{2}=\mathrm{CHCl}$, observed as a product in molecular beam ${ }^{2,3}$ and infrared chemiluminescence ${ }^{4}$ studies. However, the product yield data observed in our ${ }^{38} \mathrm{Cl}$ experiments could not be explained by Reactions 1-3 alone, and we found it necessary to include the additional reaction steps, 4-6, in order to obtain quantitative fits to the yield data.

$$
\begin{aligned}
& \mathrm{CH}_{2}{ }^{38} \mathrm{ClCHBr}^{*} \rightarrow \mathrm{CH}_{2}=\mathrm{CHBr}+{ }^{38} \mathrm{Cl} \\
& \mathrm{CH}_{2}{ }^{38} \mathrm{ClCHBr}+\mathrm{M} \rightarrow \mathrm{CH}_{2}{ }^{38} \mathrm{ClCHBr}+\mathrm{M} \\
& \mathrm{CH}_{2}{ }^{38} \mathrm{ClCHBr}+\mathrm{HI} \rightarrow \mathrm{CH}_{2}{ }^{38} \mathrm{ClCH}_{2} \mathrm{Br}+\mathrm{I}
\end{aligned}
$$

In these experiments, besides serving as a radical scavenger, $\mathrm{HI}$ functioned also as a competitor for thermal ${ }^{38} \mathrm{Cl}$ through Reaction 7. In mechanism (A), the loss of $\mathrm{Br}$ from $\mathrm{CH}_{2} \mathrm{CHBr}^{38} \mathrm{Cl}^{*}$ (Reaction 3) is very rapid such that no collisional stabilization of these radicals occurred in the pressure range studied.

$$
{ }^{38} \mathrm{Cl}+\mathrm{HI} \rightarrow \mathrm{H}^{38} \mathrm{Cl}+\mathrm{I}
$$

The alternative mechanism (B) involved the postulate that ${ }^{38} \mathrm{Cl}$ atoms reacted to form both $\mathrm{CH}_{2}{ }^{38} \mathrm{ClCHBr} *$ and $\mathrm{CH}_{2} \mathrm{CHBr}^{38} \mathrm{Cl} *$ in generally comparable initial yields, No $1,2-\mathrm{Cl}$ atom shift occurs in this mechanism, and $\mathrm{CH}_{2} \mathrm{CHBr}^{38} \mathrm{Cl}^{*}$ radicals formed in (8) either lose the bromine as in (3) or are collisionally stabilized as in (9). The stabilized radicals are postulated to undergo a 1,2bromine atom shift (10) prior to reaction with $\mathrm{HI}$ (11).

$$
\begin{aligned}
& { }^{38} \mathrm{Cl}+\mathrm{CH}_{2}=\mathrm{CHBr} \rightarrow \mathrm{CH}_{2} \mathrm{CHBr}^{38} \mathrm{Cl}^{*} \\
& \mathrm{CH}_{2} \mathrm{CHBr}^{38} \mathrm{Cl}+\mathrm{M} \rightarrow \mathrm{CH}_{2} \mathrm{CHBr}^{38} \mathrm{Cl} \\
& \mathrm{CH}_{2} \mathrm{CHBr}^{38} \mathrm{Cl} \rightarrow \mathrm{CH}_{2} \mathrm{BrCH}^{38} \mathrm{Cl} \\
& \mathrm{CH}_{2} \mathrm{BrCH}^{38} \mathrm{Cl}+\mathrm{HI} \rightarrow \mathrm{CH}_{2} \mathrm{BrCH}_{2}{ }^{38} \mathrm{Cl}
\end{aligned}
$$


This 1,2-bromine shift satisfactorily explained the absence of $\mathrm{CH}_{3} \mathrm{CHBr}^{38} \mathrm{Cl}$ as an observed product, while the measured $\mathrm{CH}_{2}{ }^{38} \mathrm{ClCH}_{2} \mathrm{Br}$ could be formed in this mechanism from reaction with $\mathrm{HI}$ of either $\mathrm{CH}_{2}{ }^{38} \mathrm{ClCHBr}$ as in (6) or $\mathrm{CH}_{2} \mathrm{BrCH}^{38} \mathrm{Cl}$ as in (11).

Of these two proposed mechanisms, the mechanism (B) involving ${ }^{38} \mathrm{Cl}$ addition to both the carbon atoms of $\mathrm{CH}_{2}=\mathrm{CHBr}$ was preferred by us because in the parallel experiments with $\mathrm{CH}_{2}=\mathrm{CHF}$, both $\mathrm{CH}_{2}{ }^{38} \mathrm{ClCH}_{2} \mathrm{~F}$ and $\mathrm{CH}_{3} \mathrm{CH}^{38}$ ClF were observed with only a weak "antiMarkovnikov" preference of 2:1 favoring addition to the $\mathrm{CH}_{2}$ end.5 Furthermore, the direction of the 1,2-bromine shift postulated in (B) is consistent with the observations reported earlier that such halogen shifts occur away from a multiple-halogen substituted carbon atom toward the $\mathrm{CH}_{2}$ end of the radical.6,7

The present experiments are being carried out with the goal of obtaining confirmation as to which of these two mechanisms is operative. The photolytic method for generating $\mathrm{Cl}$ atoms has been used in these experiments, and $\mathrm{D}_{2} \mathrm{~S}$ served as the radical scavenger. The products formed were separated by gas chromatography and analyzed by mass spectrometry. The critical postulate in mechanism (B) is the 1,2-bromine atom shift (10) to form $\mathrm{CH}_{2} \mathrm{BrCHCl}$ radicals. With $\mathrm{D}_{2} \mathrm{~S}$ as the radical scavenger, these radicals would form $\mathrm{CH}_{2} \mathrm{BrCHDCl}$ as in (12).

$$
\mathrm{CH}_{2} \mathrm{BrCHCl}+\mathrm{D}_{2} \mathrm{~S} \rightarrow \mathrm{CH}_{2} \mathrm{BrCHDCl}+\mathrm{DS}
$$

The reaction with $\mathrm{D}_{2} \mathrm{~S}$ of $\mathrm{CH}_{2} \mathrm{ClCHBr}$ radicals formed from (1) plus (5) would lead to $\mathrm{CH}_{2} \mathrm{ClCHDBr}$ as in (13) and would be distinguishable from the isomer formed in (12). If any

$$
\mathrm{CH}_{2} \mathrm{ClCHBr}+\mathrm{D}_{2} \mathrm{~S} \rightarrow \mathrm{CH}_{2} \mathrm{ClCHDBr}+\mathrm{DS}
$$

$\mathrm{CH}_{2} \mathrm{CHBrCl}$ radicals react with $\mathrm{D}_{2} \mathrm{~S}$ prior to the 1,2 -bromine atom shift, the product formed. $\mathrm{CH}_{2} \mathrm{DCHBrCl}$ is gas chromatographically separable from the isomers formed in (12) and (13). Therefore, if $\mathrm{CH}_{2} \mathrm{BrCHDCl}$ is present in the reaction products, there will be evidence for the existence of Reaction 10. In addition, the percent of the stabilization product with the structure $\mathrm{CH}_{2} \mathrm{BrCHDCl}$ will determine to what degree "anti-Markovnikov" addition is appropriate in describing the system.

Several well known chlorine atm sources include $\mathrm{Cl}_{2}, t$-butyl hypochlorite $\left(\left[\mathrm{CH}_{3}\right]_{3} \mathrm{COCl}\right)$ and phosgene $\left(\mathrm{COCl}_{2}\right) . \mathrm{Cl}_{2}$ photodissociates at $\sim 500 \mathrm{~nm}$ to give two near-thermal Cl's. $t$-Butyl hypochlorite has a weak absorption at $334 \mathrm{~nm}$ and yields one near-thermal $\mathrm{Cl}$. The third dissociates at $253.7 \mathrm{~nm}$ to give $\mathrm{Cl}+\mathrm{COCl} *$. COCl* then dissociates to provide overall $2 \mathrm{Cl}$ and one CO. All three of these were applied in the present study.

Initial work with $\mathrm{Cl}_{2}$ showed this reagent could not be used. In the dark, reaction between $\mathrm{Cl}_{2}$ and the vinyl bromide produced only $\mathrm{CH}_{2} \mathrm{ClCHClBr}$. The product was the result of a heterogeneous reaction seen by Knox. ${ }^{8}$ Vinyl chloride was not observed in the product spectrum. If atomic chlorine had been generated in the reaction system, then vinyl chloride should have been seen. It was concluded that, due to the fast rate for the heterogeneous reaction, all the $\mathrm{Cl}_{2} \mathrm{had}$ reacted before the system could be photo-irradiated. It was thought that Halocarbon wax or Teflon-coated cells could slow down this reaction, but these cells displayed the same problems as bare quartz.

The next set of reactions using $t$-butyl hypochlorite were more successful. Non-irradiated reaction mixtures displayed traces of $\mathrm{CH}_{2} \mathrm{ClCHClBr}$, thought to be the result of $\mathrm{Cl}_{2}$ impurity in the $t$-butyl hypochlorite. The irradiated samples showed vinyl chloride so $\mathrm{Cl}$ was generated. However, this yield was very low due to the small cross section for $t$-butyl hypochlorite at 253.7 nm.

The next set of experiments used $\mathrm{COCl}_{2}$. This source did not have any of the problems associated with the first two. At $253.7 \mathrm{~nm}$, the absorption cross section is large, $9.1 \times 10^{-4}$ torr $^{-1}$ $\mathrm{cm}^{-1}$ (base 10), and the quantum yield of $\mathrm{CO}$ is unity. ${ }^{9}$ In addition, work by Heicklen has shown that this reagent only reacts by a free radical mechanism. 10

The reactions were carried out with equal concentrations of $\mathrm{D}_{2} \mathrm{~S}$, vinyl bromide and phosgene ( 0.1 torr). These gases were measured into a vacuum line and then condensed in the reaction cell using liquid nitrogen. A balance of $\mathrm{N}_{2}$ was then added between 105 and 450 torr. 
The cells were removed from the liquid nitrogen and allowed to warm to room temperature. Correcting for temperature effects, the final pressures were between 406 and 1742 torr. The samples were irradiated for 5 minutes at $253.7 \mathrm{~nm}$ using a low pressure $\mathrm{Hg}$ lamp. The condensable products were then collected with liquid nitrogen and analyzed using gas chromatography followed by mass spectroscopy. A typical gas chromatogram is shown in Figure 1. The decomposition product, vinyl chloride, identified by its retention time and mass spectra, was quantified using $\mathrm{m} / \mathrm{e}=62$. The two deuterated stabilization products, $\mathrm{CH}_{2} \mathrm{BrCHDCl}$ and $\mathrm{CHDBrCH}_{2} \mathrm{Cl}$, identified by mass spectra, co-eluted and were quantified together using $\mathrm{m} / \mathrm{e}=64$. In addition, some fully protonated stabilization product, $\mathrm{CH}_{2} \mathrm{BrCH}$ in these experiments had a specified isotopic purity of $>97 \%$. It appears that HDS is formed in the reaction vessel by isotopic exchange reactions of $\mathrm{D}_{2} \mathrm{~S}$ on the glass surface, and the observed $\mathrm{CH}_{2} \mathrm{BrCH}{ }_{2} \mathrm{Cl}$ is presumably formed by $\mathrm{H}$ abstraction from $\mathrm{HDS}$ by the bromochloroethyl radicals. $\mathrm{CH}_{2} \mathrm{BrCH}_{2} \mathrm{Cl}$ was quantified using the fragment peak at $\mathrm{m} / \mathrm{e}=63$. When the yield of decomposition divided by stabilizations plotted versus the reciprocal pressure (Figure 2), a linear fit is seen. This pressure effect is consistent with an addition-decomposition mechanism occurring in the system.

Due to the co-elusion of the three stabilizition products, determination of the ratio of $\left[\mathrm{CH}_{2} \mathrm{BrCHDCl}\right]$ to $\left[\mathrm{CH}_{2} \mathrm{ClCHDBr}\right]$ required a great deal of data reduction. Treating the stabilization products as a single compound, the percent deuterium was determined on the $\mathrm{CH}_{2} \mathrm{Br}$ end, then used to find the ratio. First, a standard was run of the fully protonated product, $\mathrm{CH}_{2} \mathrm{BrCH}_{2} \mathrm{Cl}$, and each peak in the mass spectra was assigned. Then the mass spectra generated during the elution of the stabilization products were integrated. Using the assignment of peaks made with the protonated standard, the percent deuterium on the brominated side of the molecule was then determined by the change in relative peak intensities. The chlorinated side could not be used to confirm the results due to the interference of doubly charged ions. This number was then added to the percent of product that was fully protonated. The average value over the 19 runs made, $73 \%$, represents the percent of the deuterated stabilization product with the deuterium on the brominated end. The percent of the product that was the result of bromine migration is then 100 $73=27 \%$.

Using the rate constants derived in our previous studies, a computer model was developed to estimate the percent of stabilization product resulting from bromine migration in $\mathrm{CH}_{2} \mathrm{CHBrCl}$ as a function of pressure. A plot of these results, along with our experimental data, are shown in Figure 3. Our data do not show the pressure dependence predicted by the model, and more model calculations are currently being carried out to examine this. However, our average value for the percent bromine migration agrees with the model within the error of the experiment. Most importantly, this result supports the existence of a 1,2-bromine migration in the radical intermediate postulated in mechanism B of our previous work. 


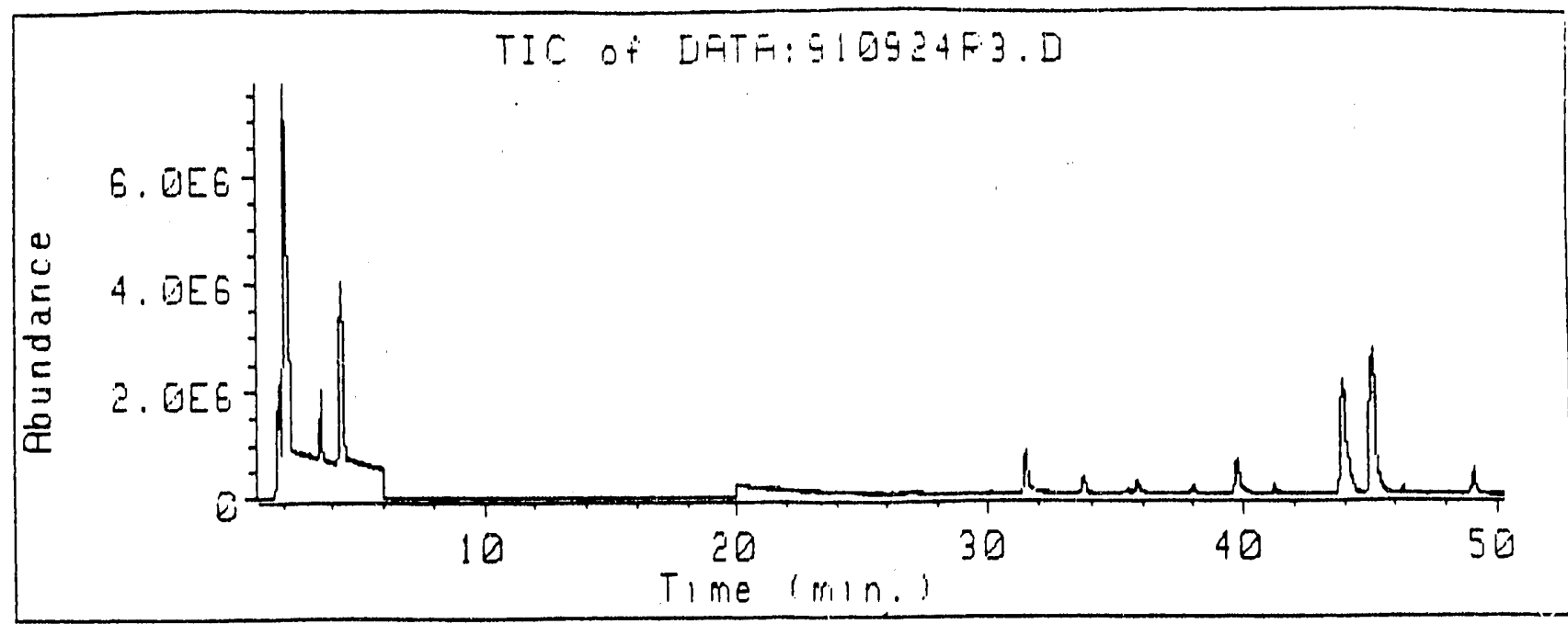

\section{TIME(MIN)}

$1.86^{*}$

$2.06^{*}$

3.55

$4.34 *$

6.00 to $20.00 *$

31.48

33.71

35.44

35.81

38.04

39.76

41.19

43.99*.

45.09

46.30

49.21
COMPOUND

$\mathrm{CO}_{2}$

$\mathrm{D}_{2} \mathrm{~S}, \mathrm{HDS}$

$\mathrm{SO}_{2}$

$\mathrm{CH}_{2} \mathrm{CHCl}$

$\mathrm{COCl}_{2}, \mathrm{CH}_{2} \mathrm{CHBr}$ (ion-multiplier off)

$\mathrm{CH}_{2} \mathrm{BrCl}$

$\mathrm{C}_{2} \mathrm{H}_{2} \mathrm{BrCl}$

$\mathrm{CH}_{2} \mathrm{ClCHDCl}, \mathrm{CH}_{2} \mathrm{ClCH}_{2} \mathrm{C}$

$\mathrm{CH}_{3} \mathrm{CHBrCl}$ (and deuterated form)

$\mathrm{C}_{2} \mathrm{H}_{2} \mathrm{Br}_{2}$

$\mathrm{C}_{2} \mathrm{H}_{2} \mathrm{BrCl}$

$\mathrm{CH}_{2} \mathrm{Br}_{2}$

$\mathrm{CH}_{2} \mathrm{BrCHDCl}$, CHDBrCH${ }_{2} \mathrm{Cl}, \mathrm{CH}_{2} \mathrm{BrCH}_{2} \mathrm{Cl}$

$\mathrm{C}_{2} \mathrm{H}_{3} \mathrm{DBr}_{2}, \mathrm{C}_{2} \mathrm{H}_{4} \mathrm{Br}_{2}$

$\mathrm{C}_{2} \mathrm{H}_{2} \mathrm{Cl}_{2} \mathrm{O}$

$\mathrm{C}_{2} \mathrm{H}_{2} \mathrm{Br}_{2}$

*Confirmed with standards (all other assignments made by mass spectra alone) 


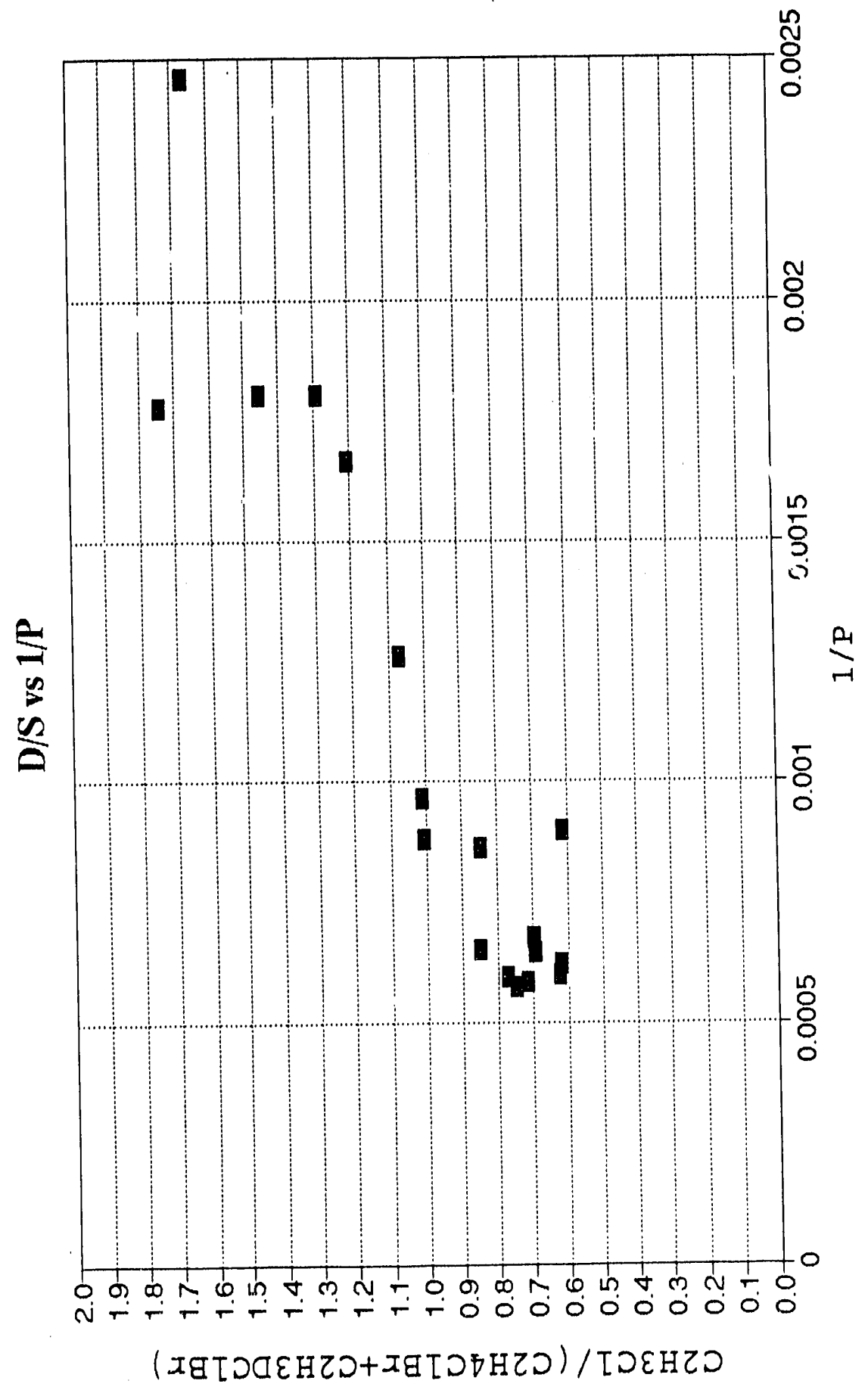




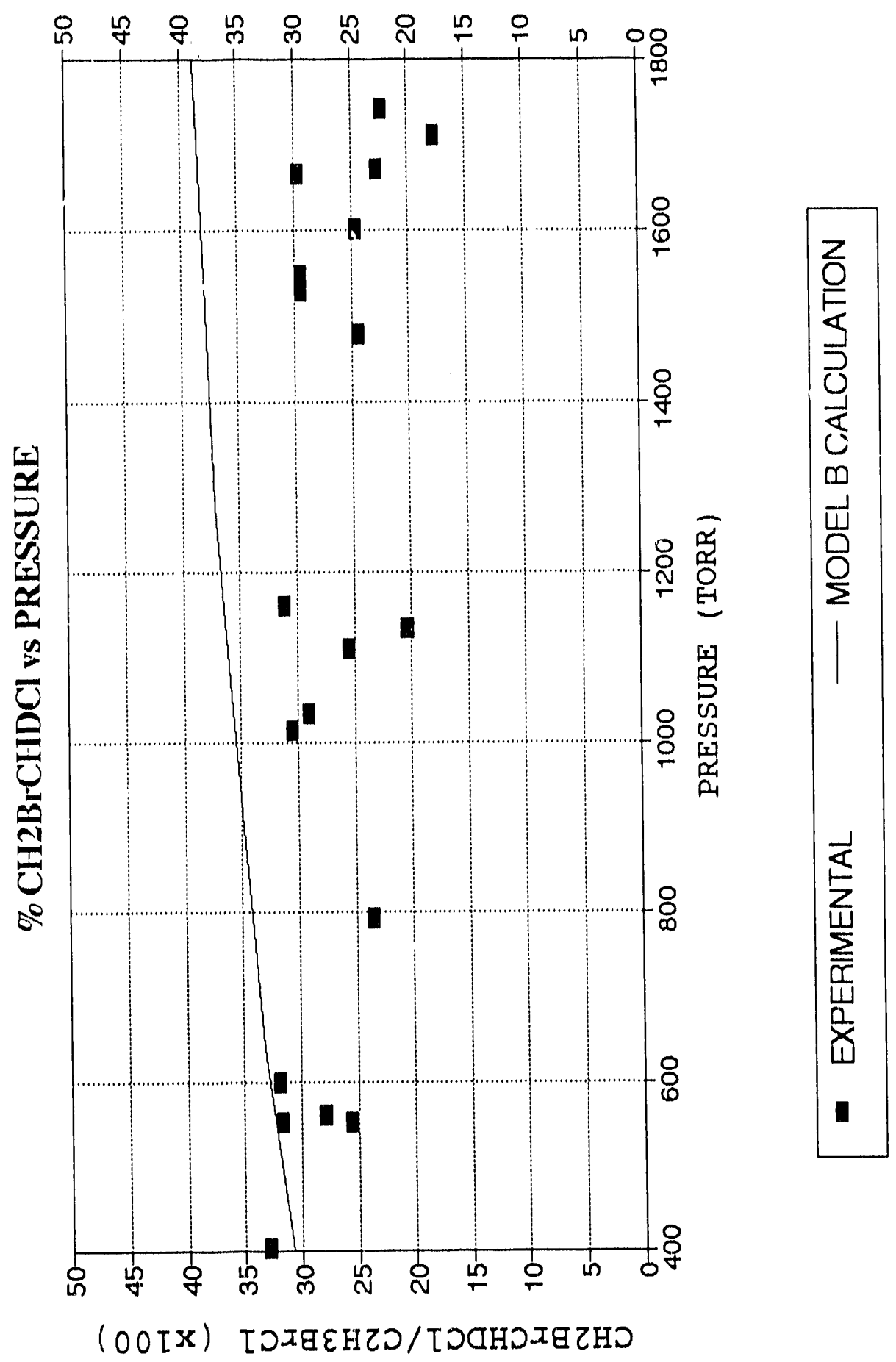




\section{REFERENCES FOR SECTION III}

1. Iyer, R.S.; Rowland, F.S. "A Long-Lived $\mathrm{C}_{2} \mathrm{H}_{3} \mathrm{ClBr}$ * Radical from the Reaction of Atomic Chlorine with Vinyl Bromide", Chem. Phys. Lett. 1983, 103, 213.

2. Cheung, J.T.; McDonald, J.D.; Herschbach, L.R. "Molecular Beam Chemistry. Unimolecular Decompsition of Chemically Activated Chlorobromoalkyl Radicals", J. Am. Chem. Soc. 1973, 95, 7889.

3. Buss, R.J.; Coggiola, M.J.; Lee, Y.T. "Molecular Beam Studies of Unimolecular Reactions $\mathrm{Cl}, \mathrm{F}+\mathrm{C}_{2} \mathrm{H}_{2} \mathrm{Rr}^{\prime \prime}$, Faraday Discussions Chem. Soc. 1979, 67, 162.

4. Durana, J.F.; McDonald, J.D. "Infrared Chemiluminescence Studies of Chlorine Substitution Reactions with Brominated Unsatured Hydrocarbons", J. Chem. Phys, 1976, $64,2518$.

5. Iyer, R.S.; Chen, C.-Y.; Rowland, F.S. "Gas-Phase Reactions of Atomic Chlorine with Vinyl Fluoride", J. Phys. Chem. 1985, 89, 2042.

6. Skell, P.S.; Parks, R.R.; Lewis, D.C.; Shea, K.J. "Bridged Bromine and Chlorine Free Radical Intermediates, Free-Radical Halogenations of 2-Halobutanes", J. Amer. Chem. Soc. 1973, 95, 6735 .

7. Friedlina, R.Kh. Advances in Free Radical Chemistry, Vol. I, Ed. Williams, G.H., Academic Press, New York, 1965, p. 211.

8. Knox, J.; Waugh, K.C. "Activated Chloroalkyl Radicals in the Chlorination of Trichloroethylene and other Olefins", Trans. Faraday Soc. 1969, 65, 1585.

9. Okabe, H. Photociemistry of Small Molecules, Wiley-Interscience, New York, 1978, p. 289.

10. Heicklen, J. "The Photolysis of Phosgene-Ethylene Mixtures", J. Amer. Chem. Soc. $1965,87,445$. 


\section{PROGRESS REPORT \\ DEPARTMENT OF ENERGY \\ RESEARCH CONTRACT DE-FG03-86ER 13469}

\section{GAS PHASE OXIDATION STUDIES OF HYDROFLUOROCARBONS AND HYDROCHLOROFLUOROCARBONS BY FTIR}

There is considerable interest in substitutes for CFC-11 and CFC-12 and their subsequent reactions in the earth's atmosphere. The proposed substitutes for the CFCs are hydrofluorocarbons (HFCs) and hydrochloroflisorocarbons (HCFCs). In the troposphere, these molecules are expected to react with $\mathrm{OH}$ radicals resulting in the formation of haloalkyl radicals. Very little information is available at the present time on the subsequent reactions of such haloalkyl radicals under atmospheric conditions. We have initiated a series of photochemical experiments with product identification and measurement by FTIR for understanding the oxidation mechanism of these haloalkyl radicals.

Our initial experiments have involved $\mathrm{HFC}-134 \mathrm{a}\left(\mathrm{CF}_{3} \mathrm{CH}_{2} \mathrm{~F}\right)$, which has been proposed as a possible substitute for CFC-12, used for air-condition, $\mathrm{g}$ and refrigeration. ${ }^{1}$ The U.V. absorption cross section data ${ }^{2}$ indicate that solar photolysıs cannot be a tropospheric removal process for $\mathrm{CF}_{3} \mathrm{CH}_{2} \mathrm{~F}$. Hence, oxidation initiated by $\mathrm{OH}$ radicals is the expected tropospheric removal process for $\mathrm{CF}_{3} \mathrm{CH}_{2} \mathrm{~F}$. The production of $\mathrm{CF}_{3} \mathrm{CHF}$ radicals from this compound can be accomplished by reaction with either $\mathrm{OH}$ (Equation 1) or with $\mathrm{Cl}$ (Equation 2).

$$
\begin{aligned}
& \mathrm{CF}_{3} \mathrm{CH}_{2} \mathrm{~F}+\mathrm{OH} \rightarrow \mathrm{CF}_{3} \mathrm{CHF}+\mathrm{H}_{2} \mathrm{O} \\
& \mathrm{CF}_{3} \mathrm{CH}_{2} \mathrm{~F}+\mathrm{Cl} \rightarrow \mathrm{CF}_{3} \mathrm{CHF}+\mathrm{HCl}
\end{aligned}
$$

Because of the greater ease of production of $\mathrm{Cl}$ atoms as compared to $\mathrm{OH}$ radicals, our initial experiments have involved the use of reaction 2 to produce $\mathrm{CF}_{3} \mathrm{CHF}$ radicals and examination of their subsequent oxidation in the presence of $\mathrm{O}_{2}$. The photodissociation of $\mathrm{Cl}_{2}$ at $340 \mathrm{~nm}$ was used to generate $\mathrm{Cl}$ atoms. Small amounts ( 2 to 4 t $\mathrm{sr}$ ) of $\mathrm{HFC}-134 \mathrm{a}$ and $\mathrm{Cl}_{2}$ are mixed with 80 to 100 torr of $\mathrm{O}_{2}$ in an FTIR cell (with potassium bromide windows) also equipped with windows (Suprasil) enabling ultraviolet (UV) radiation to pass through the cell. The cell and its contents are then subjected to UV radiation (using an Oriel 1000 watt $\mathrm{Xe}-\mathrm{Hg}$ arc lamp and a Bausch \& Lomb Monochromator) at a wavelength of 340 nanometers for incremental time intervals. After each exposure to radiation, the cell is carried to a Perkin-Elmer Model 1600 FTIR and analyzed by FTIR. The percent transmission of infrared radiation by the products is determined by subtracting the spectrum of the non-irradiated sample from the spectrum of the irradiated sample. The percent transmissions are converted to torr by use of calibration curves. Figures 1-3 show sample spectra of the parent compound (HFC-134a) and two of the products $\left(\mathrm{CF}_{2}(\mathrm{O})\right.$ and $\left.\mathrm{CF}_{3} \mathrm{CF}(\mathrm{O})\right)$. Figure 4 shows the difference spectrum obtained following a 60 -minute irradiation of a mixture of $\mathrm{HFC}-134 \mathrm{a}$ (3.98 torr), $\mathrm{Cl}_{2}$ (2.06 torr), and $\mathrm{O}_{2}$ (81.72 torr).

\section{Wavelengths used in Calibration Curves}

$\begin{array}{cc}\text { Compound } & \text { Wavelength }\left(\mathbf{c m}^{-1}\right) \\ \mathrm{HFC}-134 \mathrm{a} & 666.7 \\ \mathrm{CF}_{2}(\mathrm{O}) & 691.6 \\ \mathrm{CF}_{3} \mathrm{CF}(\mathrm{O}) & 773.9\end{array}$

NOTE: These wavelengths were chosen because of minimum absorption by the other components in the cell at these wavelengths. 

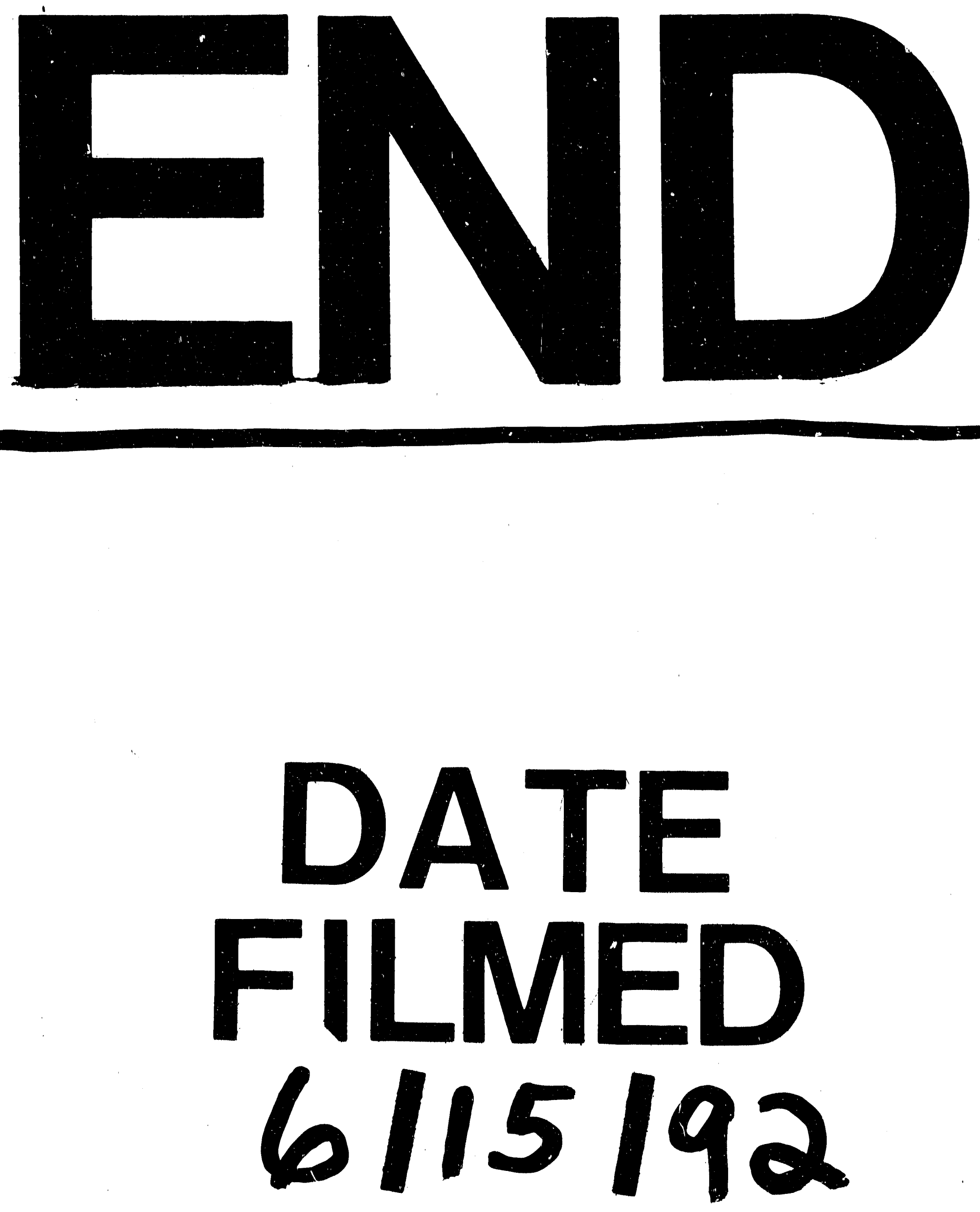
